\title{
Preliminary Tests of Innovative Eco-Friendly Furfuryl Resins and Foundry Sand Mixtures Based on These Resins
}

\author{
Jadwiga Kamińska'", Sabina Puzio', Michał Angrecki', Mateusz Stachowicz², Anna Łośs \\ 1 ŁUKASIEWICZ - Foundry Research Institute, Department of Technology, Zakopianska 73, 30-418 Cracow, \\ Poland \\ 2 Wrocław University of Technology, Faculty of Mechanical Engineering, Chair of Foundry Engineering, Plastics \\ and Automation, Ignacego Łukasiewicza 5, 50-371 Wrocław, Poland \\ 3 Grupa Azoty JRCh Sp. z o.o., E. Kwiatkowskiego 8, 33-101 Tarnów, Poland \\ * Corresponding author's e-mail: jadwiga.kaminska@iod.krakow.pl
}

\begin{abstract}
The foundry industry in Poland and EU member states is growing steadily. The alloys based on ferrous metals (cast steel and cast iron) largely contribute to this upward trend. Currently, foundries are facing the problem of increasing requirements, which enforce the production of castings characterized by high dimensional accuracy and surface smoothness with parallel elimination of casting defects. Castings are mostly made in moulding sand mixtures, which are also subject to more and more stringent requirements to meet the above-mentioned casting acceptance conditions. Additionally, moulding sands should ensure adequate mould stiffness to avoid the risk of dimensional deformations during the pouring of liquid metal to this mould and casting solidification. For these reasons, the production of this type of castings has been dominated by loose self-hardening sands with furfuryl resin, commonly called furan sands. In the group of self-hardening sands with synthetic resins, loose self-hardening sands with furfuryl resin enjoy the greatest popularity. What accounts for this fact is the high level of the reclamability of these sands, the possibility of obtaining castings with high dimensional accuracy, the ability to make intricate moulds and cores, the binding process taking place at ambient temperature, and low content of binder. Unfortunately, this technology also has some disadvantages, which include short lifetime of the sand mixture, harmful gases emitted from the sand, and currently also high cost of the sand mixture. The anticipated tightening of the environmental protection regulations in the EU countries, including limiting the content of free furfuryl alcohol in resins $(<25 \%$ by mass) and reducing the emission of furfuryl alcohol, formaldehyde and BTEX compounds at workplaces, necessitated the development of a new generation of furfuryl resins friendly to the environment. The article compares the results of testing the strength properties of foundry moulding sands using two types of resins, i.e. the resin of a new generation synthesized by Grupa Azoty JRCh and a commercial resin used in the foundry industry. Additionally, derivatographic studies of the above mentioned sand mixtures were conducted, and the loss on ignition and the amount of gases emitted by the sand mixture were determined. Melting was also carried out to study the impact of the resin used on the surface quality of iron castings.
\end{abstract}

Keywords: loose self-hardening sands; furfuryl resin; environmental protection; mechanical tests; casting surface quality

\section{INTRODUCTION}

Foundries are facing increasing demands, which enforce the manufacture of castings with high dimensional accuracy and surface smoothness while eliminating the casting defects [Jureczko et al. 2016].
A large part of castings is made in moulding sands [Mhamane et al. 2018; Khandelwal et al. 2014], which also face increasing demands to meet the above mentioned casting acceptance conditions. Additionally, moulding sand should confer adequate stiffness to the foundry mould in order to protect it from dimensional deformations 
during the liquid metal pouring and casting solidification [Hussein et al. 2013].

Currently, the binders based on furfuryl resins constitute the largest group (approx. 55\%) of binders used in no-bake moulding sands hardened without heating [Chate et al. 2017; Acharya et al. 2016].

The reason for this is, among others, high reclamability of the sand mixture, obtaining castings with high dimensional accuracy, the ability to make complex moulds and cores, binding at ambient temperature, and low binder content in the sand mixture [Bobrowski et al. 2012; Lewandowski 1997; Bobrowski 2015].

The planned tightening of environmental protection regulations in the EU countries, mainly EU Directive [Regulation (EC) No. 1272/2008], including, among others, the required reduction in the content of free furfuryl alcohol in resins ( $<25 \%$ by mass) and lower level of emissions of furfuryl alcohol, formaldehyde and BTEX compounds at workplaces, has stimulated the emergence of a new generation of environmentally friendly furfuryl resins on the market [Holtzer et al. 2013; Żymankowska-Kumon 2015].

Cooperating with Grupa Azoty JRCh and Prec-Odlew, the ŁUKASIEWICZ Research Network - Foundry Research Institute is implementing the ŻYWFUR project, the main aim of which is to produce a domestic ecological furfuryl resin. The innovative pro-ecological product is expected to have a reduced content of free furfuryl alcohol ( $<25 \%$ by mass) and/or free formaldehyde $(<0.1 \%$ by mass). In addition to limiting the negative impact on the environment, the use of the resins of a new generation will allow reducing their content in the sand mixture, which will bring positive economic effects to potential users.

\section{MATERIALS AND METHODS}

Two types of furfuryl resins were used in the study, i.e. a commercial one, widely available on the market, Resin 1 and a product of synthesis made under the ŻYWFUR project designated as Resin 2.

Table 1 gives the characteristics of the resins tested. Both resins are brown, clear liquids with similar density, viscosity and free formaldehyde content. Resin 2 is characterized by a higher content of the furfuryl alcohol with a lower percentage of nitrogen.
The binder used in no-bake furan sand technology consists of two basic components [Integrated Pollution Prevention and Control], i.e. furfuryl resin, obtained by polycondensation of furfuryl alcohol with phenol, urea or formaldehyde, and an acid catalyst (hardener).

The process of binder polymerization and hardening takes place as a result of the strongly exothermic reaction. A by-product of the reaction of polycondensation is water, which inhibits the binder hardening process (Fig. 1).

Loose, self-hardening sand mixtures containing 1 part by weight of resin and 0.5 part by weight of hardener were prepared using Grudzeń Las silica sand classified according to the $\mathrm{PN}-85 / \mathrm{H}-11001$ standard as medium sand (main fraction $0.20 / 0.16 / 0.315$ ). The paratoluene sulphonic acid was used as a hardener.

From the prepared sand mixture, standard longitudinal $22.4 \times 22.4 \times 172 \mathrm{~mm}$ specimens were made for the bending test and octal-shaped specimens for the tensile test. The sand was pre-compacted in an LUZ-1 type vibratory compaction apparatus. The mechanical tests were carried out on an LRU-2e apparatus. The lapse of time between the end of the specimen compaction process and testing was 1,2, 4 and 24 hours.

A thermal analysis was also conducted on the examined sand mixtures to assess the effect of temperature on their properties. The TG-DTA-DSC-Cp curves were plotted using an STA 449F3 Jupiter thermal analyzer coupled with QMS 403C Aëolos. During the thermal analysis, the specimens were heated to $1500^{\circ} \mathrm{C}$ at a constant rate of $10^{\circ} \mathrm{C} / \mathrm{min}$.

In the last stage of the conducted studies, meltings were carried out to determine the effect

Table 1. Characteristics of the resins tested

\begin{tabular}{|l|c|c|}
\hline \multicolumn{1}{|c|}{ Parameter } & Resin 1 & Resin 2 \\
\hline State & liquid & liquid \\
\hline Appearance & clear, brown & clear, brown \\
\hline $\begin{array}{l}\text { Density }\left(20^{\circ} \mathrm{C}\right), \mathrm{g} / \\
\mathrm{cm} 3\end{array}$ & 1,163 & 1,150 \\
\hline $\begin{array}{l}\text { Viscosity }\left(20^{\circ} \mathrm{C}\right), \\
\mathrm{mPa} \text { - }\end{array}$ & 26 & 20 \\
\hline $\begin{array}{l}\text { Free } \\
\text { formaldehyde, } \%\end{array}$ & $0,13-0,15$ & 0,16 \\
\hline Furfuryl alcohol, $\%$ & $77 \pm 1$ & $84 \pm 1$ \\
\hline Nitrogen, $\%$ & $3,5 \pm 0,5$ & $1,9 \pm 0,5$ \\
\hline
\end{tabular}



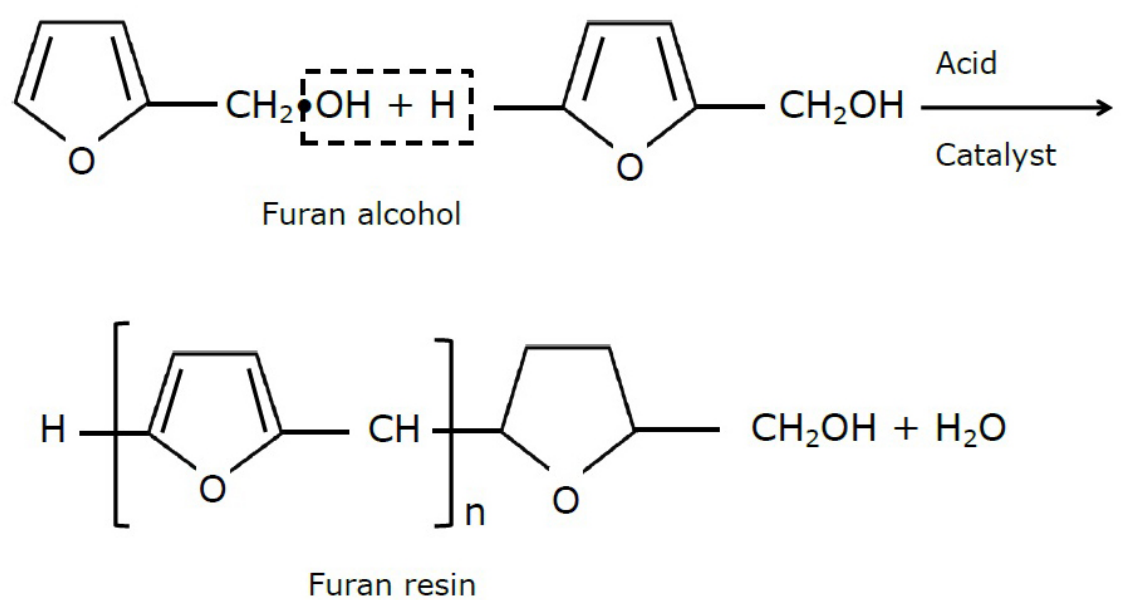

Fig. 1. The hardening mechanism of furfuryl resin [Holtzer 2014]

of resin type on the quality of the outer surface of iron castings. For reconstruction of the casting surfaces, a HITACHI scanning electron microscope (SEM), model TM-3000, and dedicated graphical and analytical software were used.

\section{RESULTS}

\section{Microscopic examinations}

The scanning images of the prepared sand mixtures were taken to study the type of bond formed between base sand grains. The microscopic examinations were performed using a SCIOS FEI scanning electron microscope. The obtained images are shown in Figure 2. A careful analysis of the scanning images shows that in neither of the two cases does the binder (resin) cover the entire surface of the base sand grains. In both cases, it only forms bridges between individual grains. This type of bond joining the sand grains together makes the casting knocking out process easier and improves the sand reclamability.

\section{Thermal analysis}

Derivatographic studies allowed for simultaneous thermal differential and thermogravimetric analyses. The changes occurring in the samples during heating were recorded in the form of two curves:

- TG graph showing changes in sample temperature over time of heating,

- DTA-differential thermal curve (examination of thermal effects of exo- and endothermic transformations).
In the entire temperature range, for the sand mixtures tested, the performed thermal analysis showed different course of TG and DTA curves.

In the case of the sand mixture based on Resin 1 (Fig. 3), the TG curve showed a gradual loss in sample mass over the entire temperature range. In the case of the sand mixture based on Resin 2 (Fig. 4), the total loss in sample mass took place up to a temperature of about $650^{\circ} \mathrm{C}$.

The changes in the sample mass up to a temperature of $200^{\circ} \mathrm{C}$ are associated with the evaporation of the water contained in the resin. Further heating results in a gradual breakdown of the binder into free radicals and/or atoms [Jeng-Jong 2010]. As a consequence of the resin decomposition, carbon and hydrogen atoms are formed, as well as methyl and propenyl radicals. Combined together, the radicals can form benzene, toluene or xylene.

The total loss in the mass of the sample based on Resin 1 was slightly higher than the loss in the mass of the sample based on Resin 2 .

In order to verify the results of thermal analysis, the following measurements were taken: the amount of gases evolved (in accordance with the BN-76/4024-05 industry standard) and loss on ignition (in accordance with the PN-83/H-04119 standard). The test results are summarized in Table 2.

Table 2. Gas evolution rate and loss on ignition (LOI) in the sand mixtures tested

\begin{tabular}{|l|c|c|}
\hline \multicolumn{1}{|c|}{ Parameter } & Resin 1 & Resin 2 \\
\hline $\begin{array}{l}\text { Gas evolution } \\
\text { rate }, \mathrm{cm}^{3} / \mathrm{g}\end{array}$ & 20,5 & 20,5 \\
\hline $\begin{array}{l}\text { Loss on ignition, } \\
\%\end{array}$ & 2,429 & 1,749 \\
\hline
\end{tabular}


a)

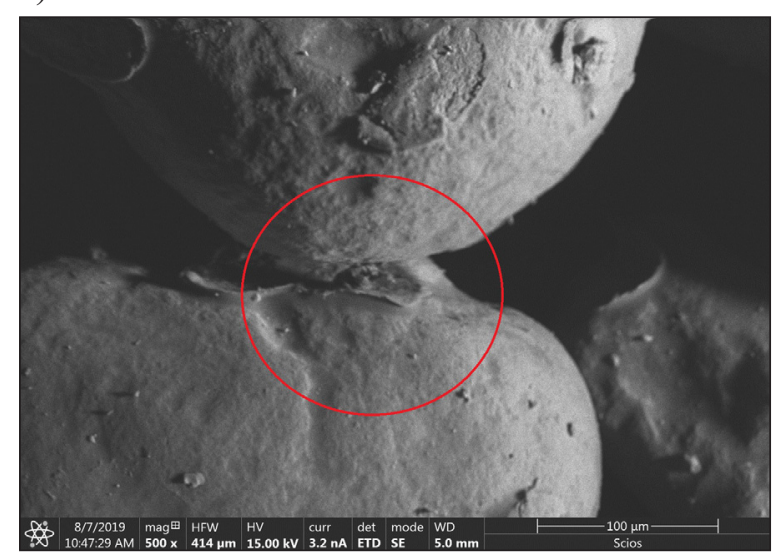

b)

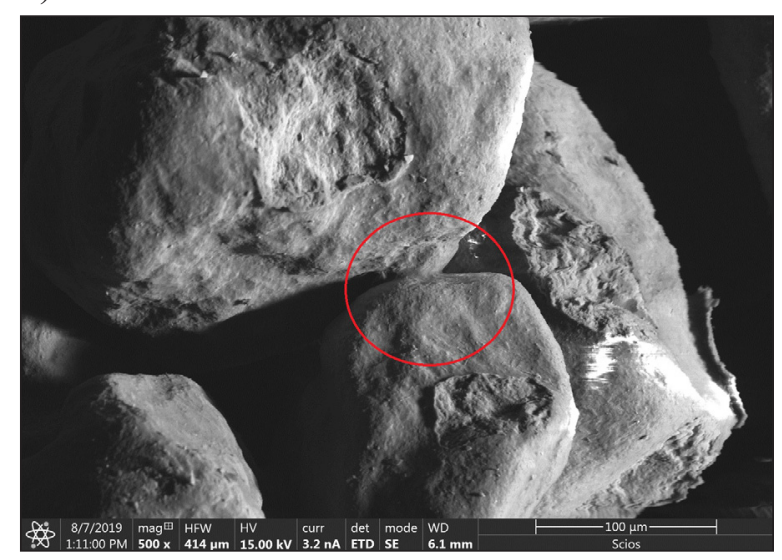

Fig. 2. Scanning images of sand mixture samples: $a-\operatorname{Resin} 1, \mathrm{~b}-\operatorname{Resin} 2,500 x$.

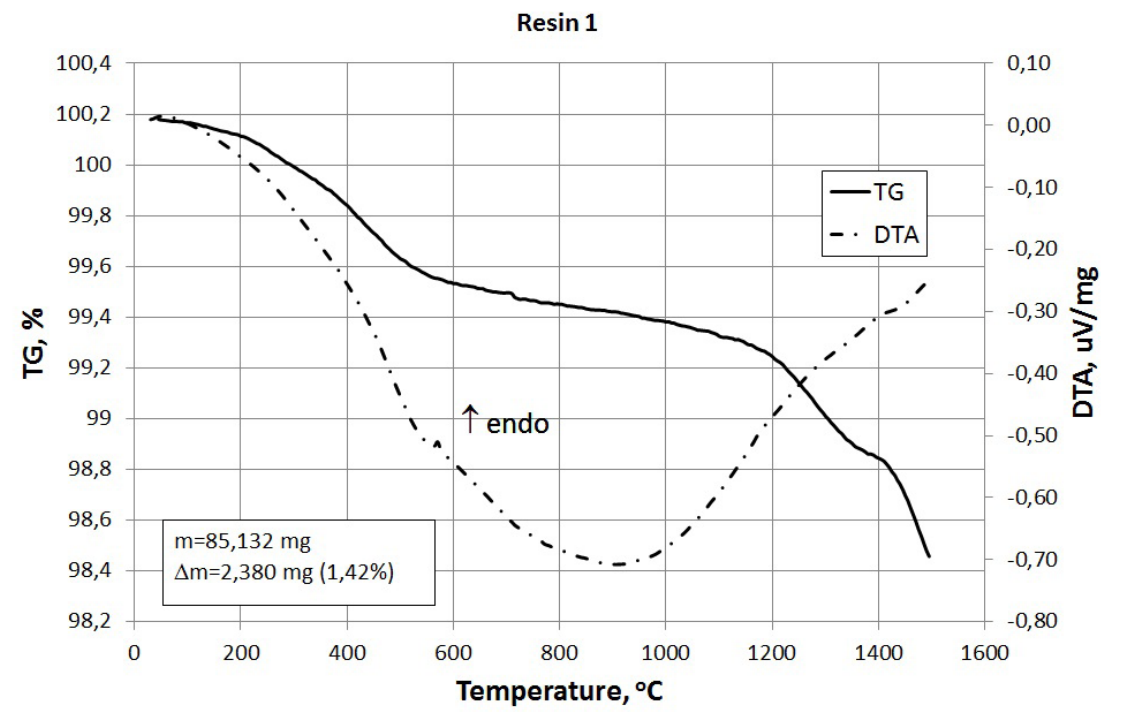

Fig. 3. The results of derivatographic analysis carried out for the sand mixture based on Resin 1 . Sample weight $\mathrm{m}=85,132 \mathrm{mg}$; weight loss $\Delta \mathrm{m}=2,380 \mathrm{mg}(1.42 \%)$. Heating speed $-10^{\circ} \mathrm{C} / \mathrm{min}$

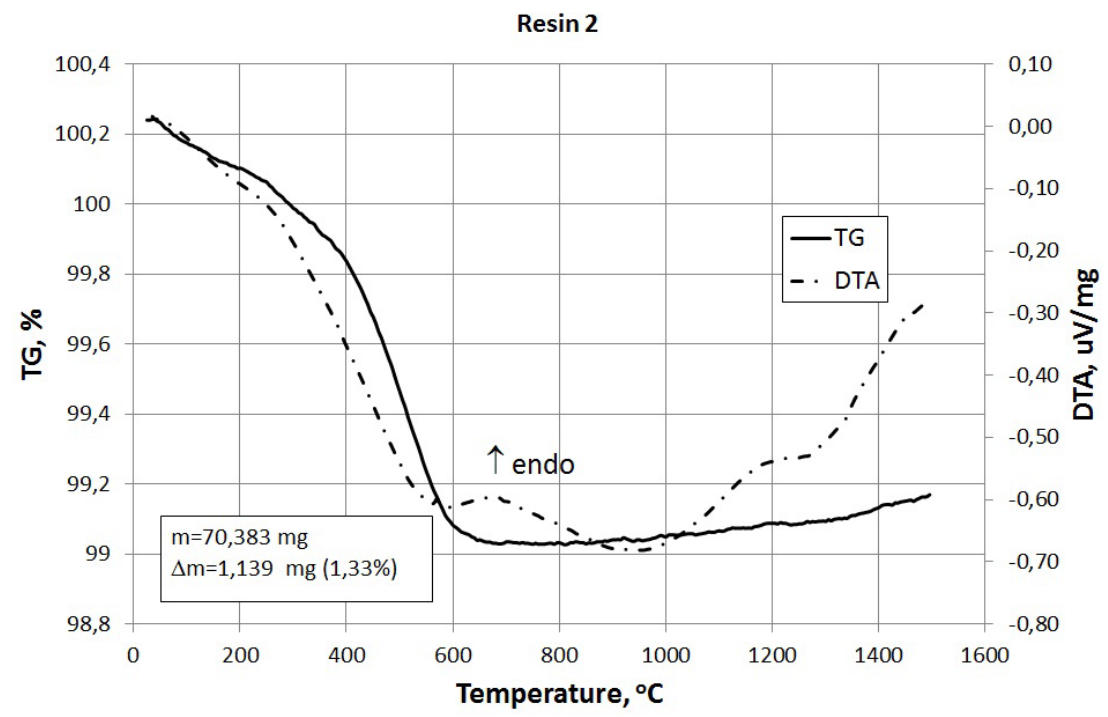

Fig. 4. The results of derivatographic analysis carried out for the sand mixture based on Resin 2. Sample weight $\mathrm{m}=70,383 \mathrm{mg}$; weight loss $\Delta \mathrm{m}=1,139 \mathrm{mg}(1.33 \%)$. Heating speed $-10^{\circ} \mathrm{C} / \mathrm{min}$ 
Both tested resins evolved the same amount of gas at $1000^{\circ} \mathrm{C}$. The loss on ignition in the sand mixture based on Resin 2 was lower by nearly $30 \%$ compared to the sand mixture based on Resin 1 , as further confirmed by the results of thermal analysis.

\section{Mechanical testing}

The tests included determination of the strength parameters of loose self-hardening sand samples as a function of the hardening time. The kinetics of the changes in technological parameters is presented in the form of diagrams on the example of bending strength (Fig. 5) and tensile strength (Fig. 6) of the moulding sand samples prepared using two types of resins tested.

The graphs show that in the case of Resin 1, the strength of the sand mixture in the first two hours of the sand maturing process was increasing very quickly, while later this increase was only insignificant. In the case of Resin 2, the strength of the sand mixture was increasing more slowly but at the same time more steadily, in an almost linear manner, throughout the entire period of hardening. After the lapse of 24 hours, the sand mixture based on Resin 2 was characterized by higher bending and tensile strengths.

\section{Casting surface quality}

A HITACHI scanning electron microscope (SEM), model TM-3000, and dedicated graphical and analytical software were used for the reconstruction of the surface of iron castings.

Prior to the roughness measurements, the surfaces of raw castings were cleaned with dry compressed air, checked for mechanical damages and marked in the places where surface reconstruction procedures were to be carried out.

All surface reconstruction procedures were performed at the same magnification, allowing the elementary segment length $1 r=239.63 \mu \mathrm{m}$ to be maintained and the electron beam source to be set at $15 \mathrm{kV}$, thus ensuring accurate observation and recording of the surface details in cast iron samples.

In the measurements of surface roughness, the following parameters were used:

- SRa - arithmetic mean of absolute values,

- $\mathrm{SRq}$ - root mean square of values,

- SRz - ten highest peaks and lowest valleys over the entire sampling length,

- SRp - maximum peak height,

- SRv - maximum valley depth,

- SRIr - profile length coefficient,

- SRSm - mean width of the roughness profile elements.

An analysis of the accuracy of the measured roughness was performed and compared with the notched profile template [Pałyga et al. 2015].

The moulds for assessment of the outer casting surface quality were made from the sand mixtures containing the above mentioned resins and were then poured with cast iron at a temperature of $1400^{\circ} \mathrm{C}$. After knocking out, castings were sandblasted and subjected to roughness tests.

Table 3 summarizes the results of studies on the roughness parameters. Figures 7 and 8 show the section measurements of roughness together with their transverse $2 \mathrm{D}$ profile.

The SRz coefficient, reflecting the value of the ten highest and lowest peaks over the entire

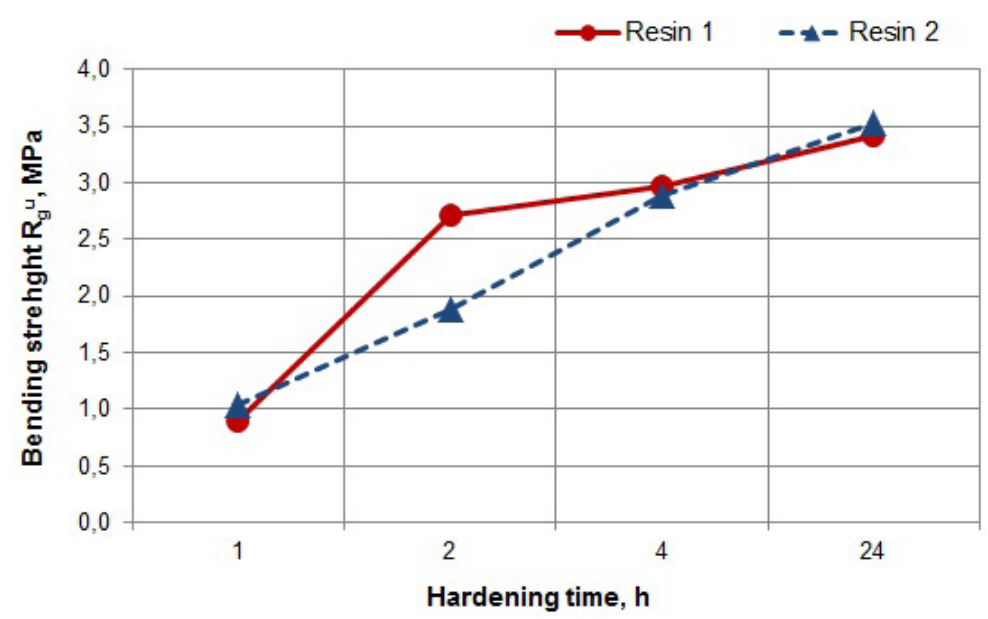

Fig. 5. Kinetics of changes in the bending strength $\mathrm{R}_{\mathrm{g}}{ }^{\mathrm{u}}$ of the tested sand mixtures 
Table 3. Test results obtained for selected roughness parameters

\begin{tabular}{|c|c|c|}
\hline Parameters & Resin 1 & Resin 2 \\
\hline SRa, $\mu \mathrm{m}$ & 5,36 & 3,94 \\
\hline SRq, $\mu \mathrm{m}$ & 6,64 & 4,79 \\
\hline SRz, $\mu \mathrm{m}$ & 31,20 & 25,86 \\
\hline SRp, $\mu \mathrm{m}$ & 14,37 & 13,10 \\
\hline SRv, $\mu \mathrm{m}$ & 16,83 & 12,75 \\
\hline SRIr, $\mu \mathrm{m}$ & 104,77 & 104,97 \\
\hline SRSm, $\mu \mathrm{m}$ & 176,65 & 84,63 \\
\hline
\end{tabular}

sampling length, is slightly lower for the sand mixture based on Resin 2. The maximum peak height and valley depth for the casting made in this sand mixture is also lower. While examining the data contained in Table 3, it can be seen that the casting made in the sand mixture with Resin 2 has lower roughness values and thus better quality of the outer surface than the casting made in the sand mixture with Resin 1.

\section{CONCLUSIONS}

The research allowed drawing the following conclusions:

- The higher the furfuryl alcohol content in the resin, the better the binder properties. Alcohol accelerates the hardening process of the resin and increases its binding capacity, which allows introducing less binder into the sand mixture.

- Decreasing the amount of binder in the sand mixture allows reducing its harmful effect on the environment, mainly due to a lower

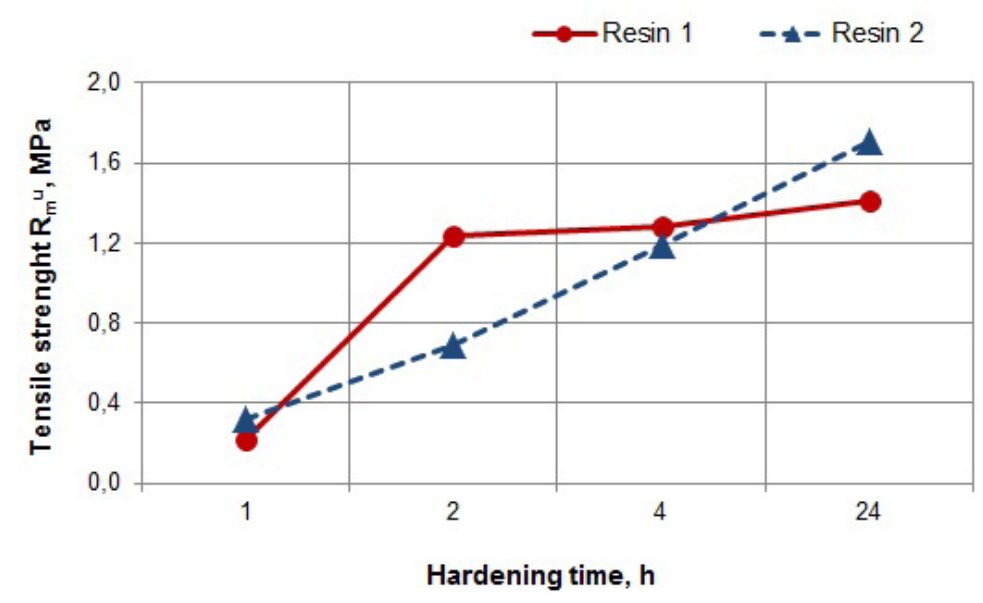

Fig. 6. Kinetics of changes in the tensile strength $\mathrm{R}_{\mathrm{m}}{ }^{\mathrm{u}}$ of the tested sand mixtures

a)

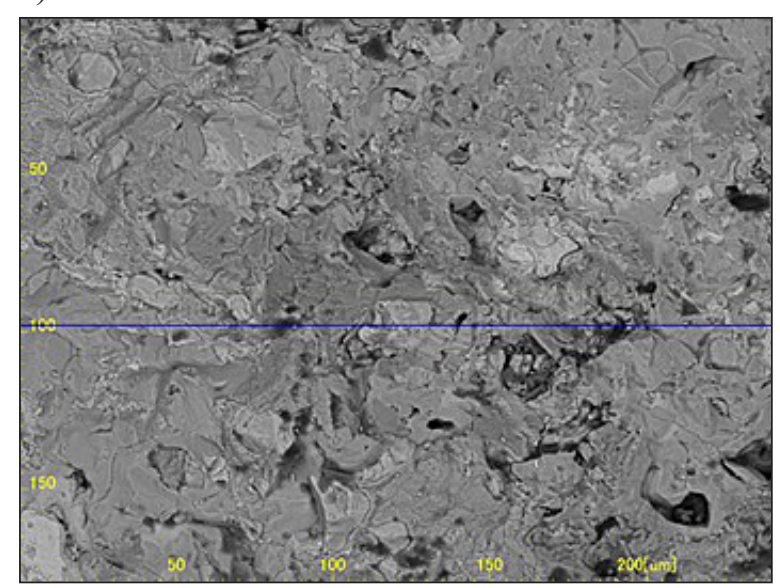

b)

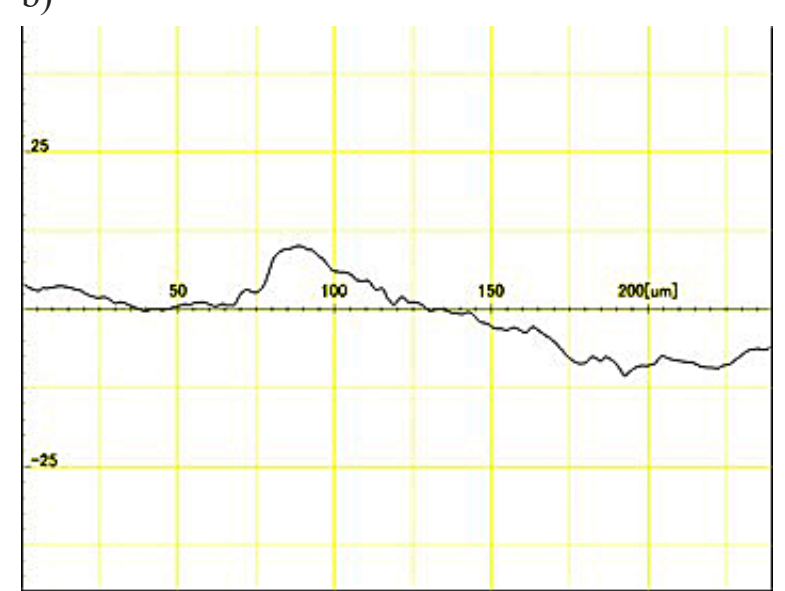

Fig. 7. The sand mixture based on Resin 1: a) the examined casting surface, b) the transverse profile of the surface 
a)

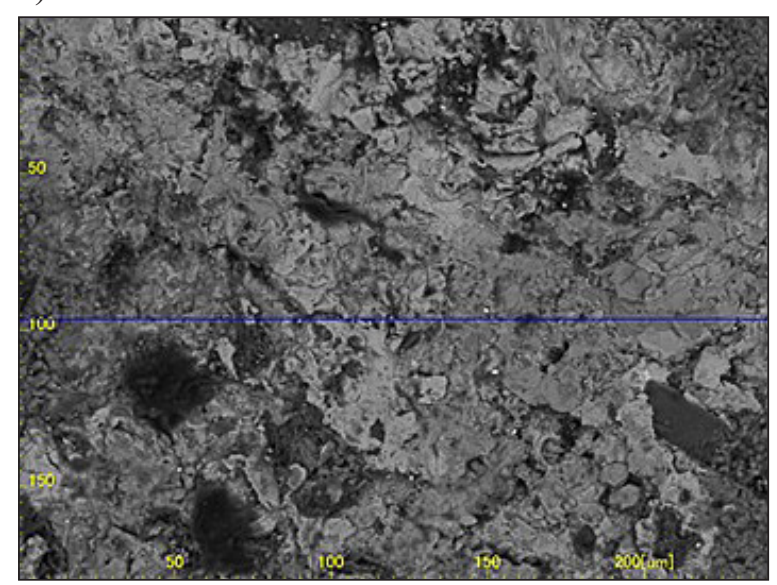

b)

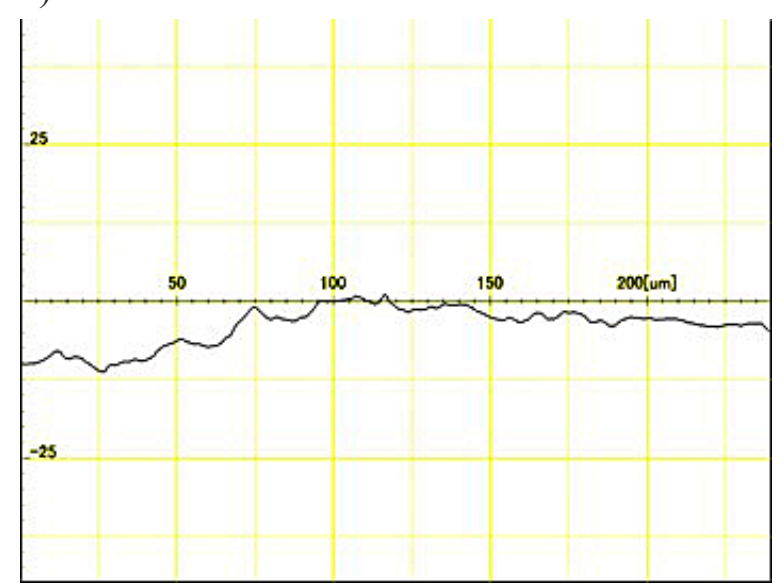

Fig. 8. The sand mixture based on Resin 22: a) the examined casting surface, b) the transverse profile of the surface

amount of compounds from the BTEX group and PAHs emitted during pouring process.

- In either case, the sand mixtures based on the two tested resins were characterized by very high strength properties. The sand mixture based on Resin 2, synthesized under the implemented project, obtained higher strength values after 24 hours of hardening than the sand mixture based on commercial Resin 1 .

- While examining the results of surface roughness tests it can be noticed that the casting made in the sand mixture based on Resin 2 had lower roughness values, i.e. a better outer surface quality, than the casting made in the sand mixture based on Resin 1 .

The obtained test results confirm that owing to the synthesis of resins carried out so far, the successful production of a new generation of proecological furfuryl resins dedicated to the foundry industry has been started. Compared to the furfuryl resins currently available on the market, the sand mixtures based on Resin 2 are less harmful to both humans and the environment, while maintaining high technological parameters.

\section{Acknowledgements}

The article was prepared as part of the projects No. POIR.04.01.02-00-0025/18-00 and LIDER/ 21/0125/L-8/16/NCBR/2017.

\section{REFERENCES}

1. Acharya S.G., Vadher J.A., Kanjariya P.V., 2016. Identification and quantification of gases releasing from furan no bake binder. Archives of Foundry Engineering, 16 (3), 5-10.

2. Bobrowski A., 2015. Structural changes in the furan resins by UV radiation and atmospheric air. Archives of Foundry Engineering, 15 (1), 5-8.

3. Bobrowski A., Grabowska B., 2012. The impact of temperature on furan resin and binder structure. Metallurgy and Foundry Engineering, 38 (1), 73-80.

4. Chate G.R., Patel GC M., Deshpande A.S, Parappagoudar M.B., 2017. Modeling and optimization of furan molding sand system using design of experiments and particle swarm optimization. Journal of Process Mechanical Engineering, 0 (0), 1-20.

5. Holtzer M., Kmita A., Roczniak A., 2014. Nowe żywice furfurylowe bardziej przyjazne dla środowiska. Archives of Foundry Engineering, 14 (4), 51-14 (in Polish).

6. Holtzer M., Kubecki M., Dańko R., ŻymankowskaKumon S., 2013. Research on the influence of moulding sand with furan resin on the environment. 4th International Symposium on High-Temperature Metallurgical Processing, 643-650.

7. Hussein N.I.S., Ayof M.N., Mohaned Sokri N.I., 2013. Mechanical properties and loss on ignition of phenolic and furan resin bonded sand casting. International Journal of Mining, Metallurgy \& Mechanical Engineering, 1 (3), 223-227.

8. Integrated Pollution Prevention and Control Reference Document on Best Available Techniques in the Smitheries and Foundries Industry May 2005 European Commission.

9. Jeng-Jong L., Gwo-Sheng T., 2010. Composition and yield of the pernicious and stench gases in furan resin sand model founding process. Environmental Engineering and Management Journal, 20 (2), 115-125.

10. Jureczko M., Pszenica M., 2016. Wpływ wybranych parametrów procesu toczenia na chropowatość 
powierzchni osi kolejowych zestawów kołowych. Modelowanie Inżynierskie, 58, 57-64 (in Polish).

11. Khandelwal H., Ravi B., 2014. Effect of binder composition on the shrinkage of chemically bonded sand cores. Materials and Manufacturing Processes, 30 (12), 1465-1470.

12. Lewandowski J.L., 1997. Tworzywa na formy odlewnicze. Wydawnictwo Akapit, Kraków (in Polish).

13. Mhamane D.A., Rayjadhav S.B., Shinde V.D., 2018. Analysis of chemically bonded sand used for molding in foundry. Asian Journal of Science and Applied Technology, 7(1), 11-16.
14. Pałyga Ł., Stachowicz M., Granat K., 2015. Evaluation of 2D and 3D surface roughness of die castings from alloy AlSi9Cu3. Archives of Foundry Engineering, 15(1), 75-80.

15. Regulation (EC) No. 1272/2008. Rozporządzenie Parlamentu Europejskiego i Rady (WE) NR 1272/2008 z dnia 16.12.2008 r. w sprawie klasyfikacji, oznakowania i pakowania substancji i mieszanin, zmieniające i uchylające dyrektywy 67/548/EWG i 1999/45/WE oraz zmieniające rozporządzenie (WE) nr 1907/2006.

16. Żymankowska-Kumon S., 2015. The BTEX emission from moulding sands with furan resin dependenceon the VOC content and loss on ignition. Metalurgija, 54 (4), 607-610. 